\title{
John Milbank
}

\section{Nic się nie kończy, dopóki nie nastąi koniec: o teologii, tadzie i władzy}

\author{
Nothing is ever over until the end: On religion, power and order
}

Artykuł pokazuje genezę oraz teologiczne, społeczne i polityczne konsekwencje rozdzielenia religii i rozumu. Przekonuje, iż separacja ta, oznaczając zanegowanie chrześcijańskiej koncepcji boskich rządów, prowadzi do niestabilności w życiu społecznym, marginalizacji i negowania religii, jednocześnie rozszerzając władzę najbardziej potężnych i skutkując chęcią przywrócenia ładu poprzez powrót do prawa religijnego i władzy w sensie teokratycznym. Autor proponuje chrześcijanom powrót do „radyklanej ortodoksji”, tzn. skupienie się na apokatastazie, immanentnej i transcendentnej boskiej obecności, uczestnictwie w trynitarnej harmonii, konieczności podporządkowania rozumu transcendencji, centralnym usytuowaniu liturgii, która odtwarza wieczny porządek. W tym zakresie autor wskazuje na rolę teologii, która powinna przezwyciężyć dotychczasowe przeciwstawienie rozumu i wiary i stać się nauką zajmującą się wszelkiego typu doświadczeniami, tworzącą całościową wizję.

Słowa kluczowe: religia, rozum, nauka, władza, sekularyzacja, teologia, ortodoksja

The article shows the origins and the theological, social and political consequences of the separation between religion and reason. It argues that this division means the negation of the Christian concept of divine governance, leads to instability in social life, to the marginalization and negation of religion and at the same time to the expansion of power of the most powerful ones; it also results in the willingness to restore the order by going back to the religious law and power in the theocratic sense. The author proposes to the Christians the return to "the radical orthodoxy", i.e. to focus on apocatastasis, immanent and transcendent divine presence, participation in the Trinitarian harmony, the necessity of the subordination of reason to transcendence, the centrality of liturgy that re-enacts the eternal order. In this regard, the author emphasizes the role of theology, which should overcome the existing opposition of reason and faith and become the science that deals with all kinds of experiences and creates the vision as a whole.

Key words: religion, reason, science, power, secularization, theology, orthodoxy 
I.

Nic się nigdy nie kończy. Nie tak dawno temu, wracając z urlopu w Irlandii przejeżdżałem przez Carrickfergus, protestanckie miasteczko w zamieszkiwanej przez protestancką większość Północy. Tam, na nabrzeżu i, rzecz jasna, na tle imponująco nietkniętego Zamku, stał pomnik holenderskiego księcia, a później króla Anglii, Wilhelma Orańskiego, będącego przedmiotem silnie antypapistowskiego kultu „króla Billego”. Z rozdrażnieniem stwierdziłem, że na pomniku widniała data 1990, przypadająca już na okres po złagodzeniu najgorszego etapu nie tak dawnych niepokojów.

Wydarzenia, które upamiętnia, mogą nam się wydawać, być może niesłusznie, samą końcówką wojny religijnej w Europie pod koniec XVII w. Przyjmując rozszerzone założenie o spóźnieniu i anachronizmie, skłonni jesteśmy postrzegać współczesne irlandzkie spory, które mogą zostać ponownie tragicznie rozniecone przez głosowanie nad brexitem, jako przejaw zacofania na dalekim krańcu Europy. Jednak czy niedawne konflikty katolicko-protestanckie w północnej części wyspy były zaledwie pozostałością, cofnięciem się w przeszłość, czy raczej zwiastunem nowej globalnej ery, w której skojarzenie religii z przemocą i terroryzmem stało się zastraszającą normalnością, a nie dziwaczną aberracją?

Dzisiaj, pod względem relacji z Unią Europejską, mozolne starania Anglii zaczynają wyglądać łudząco podobnie do mozolnych starań Irlandii. Nic się nigdy nie kończy, ponieważ postromantyczny układ państw narodowych jest z natury niestabilny, gdyż tożsamości pozostają złożone i bywają podważane. Czy Ukraińcy są Rosjanami, czy Katalończycy i Baskowie są Hiszpanami, a Bretończycy Francuzami? Czy jedność Włoch jest nienaruszalna? Czy powinien nastąpić podział Belgii? Czy Flamandowie powinni na zawsze pozostać rozproszeni między trzema państwami? Czy Skandynawia powinna, na wzór Zjednoczonego Królestwa, w jakimś stopniu zjednoczyć się politycznie? I tak dalej. Ponadto owej niepewności etniczno-politycznej często towarzyszy niepewność religijna, jak widać na przykładzie Rosji i Europy Wschodniej. We współczesnej Francji napięcia polityczne otaczają nie tylko rosnącą populację muzułmańską, ale i coraz bardziej liczną imigrację protestancką. W obu przypadkach dostrzega się niekiedy zagrożenie dla odziedziczonych tożsamości, zarówno katolickiej jak i świeckiej, w wyniku czego te ostatnie zdają się poniewczasie łączyć i uznawać obszary wspólnego, jak się okazuje, asumptu kulturowego [Debray 2017].

O ile postromantyczny układ był mniej niż niezmienny, o tyle wcześniejszy, postwestwalski także bardzo szybko się takim okazał. Cuius regio, eius religio sprawdzało się tylko pod warunkiem, że granice państwowe i wyznaniowe mniej więcej się pokrywały, lub przynajmniej zostały skoordynowane. $\mathrm{W}$ takich wypadkach konflikty religijne wydawały 
się nieaktualne, a odstępstwa religijne ograniczały się do pasywnej mniejszości. Ale jeśli Irlandia stanowiła pod tym względem wyjątek, to była nim, w nieco odmiennym sensie, również Wielka Brytania, która, mimo położenia niemal na zachodnim krańcu Europy, odegrała centralną rolę w procesie europejskiej modernizacji.

Co więcej, brytyjskie fiasko w rozwiązaniu kryzysu Reformacji, a więc i osiągnięciu pełnej nowoczesności (czego sytuacja Irlandii jest jedynie skrajnym przykładem w ramach brytyjsko-irlandzkiego archipelagu), łączy się być może w sposób pozytywny z jej ultramodernizacją. O jakie fiasko chodzi? O akceptację, po tak zwanej Chwalebnej Rewolucji 1689 r., radykalnej różnorodności religijnej pomiędzy anglikanizmem a areligijnością oraz dość drastycznie odmiennych (w coraz większym stopniu) prądów w samym anglikanizmie, które wyglądają dziwnie z punktu widzenia wszystkich innych wyznań protestanckich. $\mathrm{W}$ istocie podziały te stanowiły nieco bardziej przytłumione echo wielkiego konfliktu między katolicyzmem a protestantyzmem - o czym w sposób szczególny świadczą kontynuowane w XVIII w. związki Wysokiego Kościoła anglikańskiego z jakobitami, a także z katolikami i kryptokatolikami, szczególnie mocnymi na celtyckich obrzeżach [Monod 1989; Szechi 1994].

W jaki sposób ta wczesna, utrzymująca się do tej pory cecha modernizmu łączy się dialektycznie z ultramodernizacją? Poprzez zachęcanie do stworzenia neutralnej, niereligijnej mowy odwołującej się do rozumu i nauki jako norm publicznie obowiązujących - lub raczej poprzez zwrócenie się Okrągłogłowych, przekształconych następnie w kontestujących Wigów, a także skierowanie się niskokościelnych środowisk, w tym bardziej pragmatycznym kierunku. Otrzymując brytyjską spuściznę, Stany Zjednoczone stały się pierwszym narodem zachodnim opartym na rozumie bardziej niż na religii, czy raczej na religii rozumu. Francja poszła ich śladami - choć w tym przypadku prawdopodobnie był to także wynik nierozwiązanych napięć wynikających ostatecznie z Reformacji, wojen religijnych, Ligi Katolickiej i przerwanego buntu Frondy.

Faktycznie należy myśleć o Oświeceniu, które pomogło wygenerować te dwie rewolucje, bardziej w kategoriach długiej Reformacji, niż o Reformacji jako proto-Oświeceniu. Oświecenie było bowiem naznaczone przez unitarianizm i masonerię w dużo większym stopniu niż przez oczywistą niereligijność [Barnett 2003; Jacob 2006]. Z tej samej perspektywy wyraźny wyjątek brytyjsko-irlandzki na krańcu Europy zaczyna wyglądać znacznie mniej wyjątkowo. Prawdopodobnie nie jest tak, że Anglicy uniknęli potrzeby świeckiej rewolucji, na wzór francuskiej, dzięki ugruntowanemu pluralizmowi i roli jaką odegrał dość rewolucyjny protestantyzm. To raczej (jak wywnioskowali Edmund Burke i William 
Cobbett) rewolucja francuska była późnym dziełem radykalnej Reformacji - „deistycznych” wolnomularzy; niezależnie od tego, że stanowiła zemstę jansenistów wobec jezuitów i hugenotów w kontekście odwołania edyktu z Nantes, jak podkreślają współcześni nam historycy [Burke 2001; Barnett 2003; Cobbett 2012]. Podobnie jak w przypadku angielskiej reformacji, jej głównym aktem było zajęcie majątku kościelnego, podczas gdy argumenty dotyczące zarządzania Kościołem, jak twierdzi William Doyle, były głównymi przyczynami przejścia od reformy konstytucyjnej do rewolucji republikańskiej [Doyle 2001].

\section{II.}

Można by twierdzić, że sama religia zapewnia ład jako legitymizację i kontrolę opartą na wzorcu rytualnym ${ }^{1}$ : tak więc po upadku jednoczącego ładu europejskiego, jakim było chrześcijaństwo, w następstwie rewolucji musiały pojawić się różne kwestionowane symulakra chrześcijaństwa, z których wszystkie pozostały w głównej mierze religijne, aż do bardzo niedawna. $\mathrm{W}$ tym znaczeniu Bóg dopiero niedawno ponownie pojawił się w kręgu uwagi publicznej, chociaż w rzeczywistości nigdy nie odszedł, nawet jeśli pozostawał czasem na wpół ukryty za pragmatycznymi rozwiązaniami politycznymi, które nie do końca ujawniały swoją religijną legitymizację. Jednak krwawe podziały ideologiczne, które nastąpiły po rewolucji francuskiej, doprowadziły do intensyfikacji wcześniejszych brytyjskich prób mediacji i obalenia podziałów religijnych w imię Nauki i Rozumu. Teraz, wraz z Augustem Comte’m, quasi-religijny i „negatywny” abstrakcyjny idealizm Oświecenia, szukający „emancypacji” w imię praw itd., zostaje porzucony przez wielu w imię czysto „pozytywnego" kultu tego, co jest faktem i pragmatycznie działa. W wyniku wyostrzenia teorii Hobbesa aż do porzucenia jego liberalnego rozwiązania, ład wywołuje niepokój, a tradycyjna religia zostaje odrzucona. Zamiast tego pozostaje tylko władza i środki władzy (Nietzsche jest jedynie odmianą powyższego). Ponieważ jednak porządek wciąż jest nieodzowny, sama władza ma stać się kultem; sprawujący władzę mają rządzić i zapewniać integrację na podstawie swojej wiedzy i promowania „człowieczeństwa” jako zdolności panowania nad naturą, wewnątrz natury, a jednak poza nią [Cowling 1963].

Dopiero z wraz z pojawieniem się pozytywizmu, z powodów politycznych i ideologicznych zaczyna się historycznie „konflikt” między nauką i religią, który pozostaje konfliktem całkowicie politycznym. Faktycznie nie była to jedyna reakcja na Oświecenie: obok pozytywizmu dochodziło przez cały XIX w. do odrodzenia ewangelickiego, pietystycznego, katolickiego i prawosławnego, i to na zasadach rywalizacji. Powstawały również istotne hybrydy: sam

1 Przeciwstawienie nauki jako władzy - religii jako ładowi wywiodłem z Homo Deus Yuvala Noaha Harariego [Harari 2016]. Jednak niniejszy esej jest w podtekście krytyczny wobec jego historiografii i twierdzeń. 
pozytywizm był ciekawą inwersją okazjonalizmu, ontologizmu i woluntaryzmu postrewolucyjnej reakcji katolickiej, a później, podobnie jak w przypadku Action Française, ta inwersja została ponownie odwrócona: tam, gdzie władza została raz usankcjonowana, może zostać ponownie ochrzczona przez teologię woluntarystyczną i fundamentalistyczną (intégriste) jako mimo wszystko ład religijny [Milbank 2006: 51-74].

Podczas gdy XVIII w. należał jeszcze prawdopodobnie do okresu długiej Reformacji, religii, która stała się racjonalistyczna, ale pozostała religią, XIX w. był bardziej paradoksalnym okresem równoczesnego odrodzenia się bardziej autentycznych form chrześcijaństwa obok o wiele bardziej zjadliwego i wyraźnego ateizmu, powiązanego także po raz pierwszy z czystym scjentyzmem. Jak argumentował Charles Taylor, następstwo romantycznej reakcji przeciwko Oświeceniu przyniosło sytuację nie tyle bezspornego sekularyzmu, ale raczej z samej natury kwestionowanych i nierozwiązywalnych kwestii dotyczących wiary i niewiary [Taylor 2007].

Co zatem z wiekami XX i XXI? Można argumentować, że da się podzielić ten okres na cztery różne epoki. W pierwszej, rozciągającej się od około 1900 do 1945, panowały formy ateistycznego pozytywizmu skupione wokół naturalistycznych quasi-religii rasowych lub klasowych, ale ostatecznie zostały pokonane, z opóźnieniem w przypadku komunizmu trwającego do 1990 r. W drugiej, między 1945 r. a 1990 r., powstał na pewien czas historyczny kompromis między chrześcijaństwem a odnowionym Oświeceniem wokół humanizmu, zapisanego w koncepcjach praw uniwersalnych i ludzkiej godności [Moyn 2015]. Przez krótki okres, od 1990 r. do 2001 r., wydawało się, że ten kompromis może ogólnie zwyciężyć i doprowadzić do heglowskiego końca historii. Jednak od 2001 r. do teraz kompromis ten ulegał różnym zawirowaniom; powróciły scjentystyczne i ksenofobiczne, czasem religijne formy pozytywizmu, wraz z, w dużej mierze bezprecedensowym czynnikiem, jakim jest wyzwanie islamu na granicach i wewnątrz samej Europy Zachodniej. Wszystko to w pewnym sensie przywraca sytuację XIX-wieczną. Wraz z XIX-wiecznym paradoksem. Jesteśmy bowiem obecnie świadkami jednoczesnego dalszego spadku religijności, któremu towarzyszą przykłady różnych silnych przebudzeń, szczególnie jeśli mówimy w kategoriach globalnych. Jeżeli Bóg powrócił, to nie dlatego, że się w Niego wierzy, ale przez to, że znów bardzo dużo się o Nim mówi, choć często bez przygotowania i odpowiedniej wiedzy. Nade wszystko, gdy w drugiej, niedawnej epoce od 1945 r. do 1990 r., religia wydawała się zmarginalizowana jako niekontrowersyjna i nieszkodliwa, nawet jeśli była postrzegana jako sentymentalna i niemądra, to teraz wierzenia religijne i religijna praktyka etyczna są mocno podważane, może bardziej niż kiedykolwiek wcześniej. 
Dlaczego tak się stało? Wydaje się, że istnieje wiele zazębiających się powodów. Po pierwsze, świeckie ideologie lub quasi-religie, takie jak marksizm, socjologia i freudyzm, drastycznie straciły swoją wiarygodność w procesie, który sięgał korzeniami aż do lat sześćdziesiątych. Powstająca pustka postmodernistycznego relatywizmu została szybko wypełniona postulatami ustanowienia ontologii wyłącznie opierając się na weryfikowalnych naukach przyrodniczych. Często wiąże się to z nową ideologią świecką, której treść jest nie tyle pozytywnym zastąpieniem religii, ile negatywną wrogością wobec niej, nawet jeśli podejmowane są dość komicznie, acz wytężone wysiłki, aby przekształcić ten negatywizm w treść dającą przyczynek do działania, tak jak w przypadku „humanistycznych ceremonii pogrzebowych”, które naturalnie są zarówno bardziej, jak i mniej żałobne niż te prawdziwe.

Jednak nie należy rozumieć „Dawkinsizmu” jako substytutu zagubionej ideologicznej nadziei, a raczej w kategoriach przywrócenia czystości zawsze centralnej pozytywistycznej treści. Zapewne pozorna pozytywność starszych ideologii zawsze przykrywała skrycie negatywny, antyreligijny rdzeń. Zniszczenie tego, co ikoniczne, symboliczne i znaczące tak, by pozostawić jedynie czystą władzę i jej kult, zawsze leżało w sercu faszyzmu, nazizmu i komunizmu. Dawkinsizm w sposób bardziej jednoznaczny bierze w objęcia scjentyzm, który jak zwykle ściśle wiąże się ze świeckością, nawet jeśli sam Dawkins, co mimo niekonsekwencji można uznać za jego zasługę, zachowuje sentymentalną warstwę humanistyczną. Bo chociaż filozofia i historia nauki po latach 60-tych rzeczywiście relatywizowała przez jakiś czas twierdzenia naukowe, to przynajmniej w Wielkiej Brytanii wojujący scjentyzm pozostawał zaledwie w uśpieniu. Od czasów Thomasa Huxleya uzasadnienie ateizmu było często ukrytym celem brytyjskiej biologii (podobnie jak miękkie pogaństwo i domniemany kulturowy racjonalizm bywają skrytym, ohydnym celem Oxbridge Classics), zamiast być jej godną ubolewania konsekwencją, jak argumentował heterodoksyjny biolog z Cambridge, Rupert Sheldrake [Sheldrake 2013: 13-27, 291-317]. W ten sposób Dawkins stanowi wynurzenie się na powierzchnię czegoś, co dotychczas było ukryte. Poza Dawkinsem, bardziej wojowniczy neopozytywizm ogłasza teraz, że tylko dane informacyjne są prawdziwe, a istoty ludzkie sprowadzają się do loci input-output. Ludzka wolność i unikalna inteligencja zdolna tworzyć i oceniać są odrzucane ${ }^{2}$. Pod względem politycznym jest to oczywiście program zmierzający do zwiększenia władzy ekspertów i proletaryzacji, pacyfikacji, a być może nawet częściowej eksterminacji reszty populacji.

2 Patrz: P. Mason, Postcapitalism [Mason 2016]. Pesymistyczne aspekty tej książki są bardziej przekonujące niż te optymistyczne. Dane wykraczają poza zasięg kapitalizmu nie bardziej niż kiedyś miała to robić produkcja - w rzeczywistości, zarówno dane jak i produkt, w ich domniemanej czystej faktologicznej pozytywności, są produktami kapitalizmu i kapitalizm kontroluje (jak w przypadku Google’a), w większości wypadków, naszą pozorną wolność w obracaniu danymi. 
Po drugie, można by przypuszczać, że powodem tego wynurzenia się na powierzchnię jest nie tyle oburzenie, że religia wciąż trwa, ile lęk, że może powrócić w następstwie upadku świeckiej nadziei politycznej i terapeutycznej. Pomimo wciąż występującej erozji religii, istnieją wyraźne oznaki ożywienia w Europie wśród bardziej wykształconych środowisk w erze, w której tylko wyrafinowana religia wydaje się oferować silne, rozległe i dające nadzieję światopoglądy. I tak, do pewnego stopnia, histerię nowego ateizmu, widoczną już w latach dziewięćdziesiątych, można potraktować, z perspektywy czasu, jako profilaktyczny protest przeciwko chrześcijańskiemu ożywieniu intelektualnemu.

Po trzecie, wygodnie agnostyczna filozofia XX w., zarówno fenomenologiczna jak i analityczna, uległa metakrytyce swojego najważniejszego stanowiska [Milbank 2007: 452-500; Milbank 2010: 68-117]. Podstawowe granice chroniące przed spekulacją zostały zdekonstruowane, a w konsekwencji poza dogmatycznym sceptycyzmem, którego dogmatyzm został z kolei zakwestionowany [Priest 1995: 236-240], widzimy obecnie powrót do jawnie spekulatywnej metafizyki, naturalistycznej lub spirytystycznej w formie. Praktyczny aspekt tej gwałtownej transformacji (która wprawiła w zakłopotanie wiele starszych pokoleń akademickich) dotyczy nieadekwatności etycznego humanizmu opartego na konsensie co do prymatu negatywnej wolności i minimalnego zadowolenia. W sytuacji zwiększonej różnorodności kulturowej i etnicznej szybko okazuje się, że ludzkie pojmowanie dopuszczalnej wolności i zakresu zadowolenia jest bardzo różne, co skłania do ekstremizmu, jeśli takie pojęcia nie są łagodzone przez opartą na wiedzy refleksję, jak twierdził Quentin Meillassoux [Meillassoux 2006]. Podobnie, kiedy humanizm ostatecznie wyzbył się chrześcijańskiego zakotwiczenia, zaczęto kwestionować świętość życia zarówno w chwili narodzin, jak i śmierci, psychiczne, poza cielesnym, znaczenie seksu i nienaruszalność danej nam tożsamości biologicznej, szczególnie płciowej.

Nieuchronnie ten ostatni rozwój oznaczał praktyczne, a nie tylko teoretyczne zderzenie całkowicie zsekularyzowanych ludzi z tymi, którzy nadal trzymają się chrześcijańskiej wiary, dla których niewierzący, w swoim dążeniu do obrony człowieczeństwa, w rzeczywistości je porzucili i zaczęli sankcjonować morderstwo, tak w przypadku aborcji, jak i w przypadku zgody na fizyczne samookaleczenie przy rzekomej medycznej zmianie płci, a ostatnio nawet celowej amputacji kończyn. Nie wspominając o przerażającym i niekontrolowanym przyzwoleniu na eutanazję zarówno w Holandii, jak i w Belgii.Cokolwiek myśli się o tych sprawach, istota polega na tym, że z powodu tego rodzaju sporów pojęcie tolerancji religijnej jako takiej staje się z natury problematyczne. W jakim stopniu poszczególnym wierzącym lub zgromadzeniom religijnym można byłoby przyznać status wyjątku w odniesieniu do nowych świeckich norm dotyczących narodzin, śmierci, seksualności i płci, jeśli tym samym 
dochodzi do naruszenia tego, co obecnie uznaje się za podstawowe prawa człowieka? Przede wszystkim, czy zgromadzenia religijne posiadają jakąkolwiek umocowaną władzę stanowiącą, aby móc ograniczać działania i przekonania swoich członków, jeżeli są oni uważani za przede wszystkim obywateli, którym z definicji przysługuje taka sama jak innym autonomia? Szczerze mówiąc nie istnieje już zbiorowy konsens co do wartości i zakresu tolerancji religijnej. Zamierzchła noc nierozwiązywalnego sporu religijnego nagle zapadła nad naszym świeckim dniem. Zaiste, wydaje się, że jednak nic się naprawdę nie kończy.

W przyszłości te nieporozumienia mogą się jedynie zaostrzać, gdy dalsze rozszerzanie władzy i możliwości będzie przedstawiane jako zasadniczo dobre, co, przy całej egalitarnej retoryce, może sprowadzać się tylko do jeszcze większej wolności dla najbardziej potężnych. Czytając te zjawiska przewrotnie, w duchu J. R. R. Tolkiena i C. S. Lewisa, powiedzielibyśmy, że nie jest to triumf nauki nad przesądem, ale zwycięstwo czarnej, jako że obojętnej, magii kontroli (która często manipuluje siłami fizycznymi i powiązaniami, których natury nie w pełni rozumie) nad białą magią sztuki i liturgii, która dopuszcza pewne magiczne pokrewieństwo między duszą a materią, oraz pewną teurgiczną zdolność pewnych zaklęć do pośredniczenia w obcowaniu z boskością [Lewis 1965; Tolkien 1972]. I nawet jeśli czarna magia scjentyzmu przeczy temu pokrewieństwu, to jej nekromancja polega właśnie na skrywanym przez posiadających wielką władzę psychicznym upodobaniu do procesów ślepej mocy, z którymi pragną być jednością, nawet paradoksalnie wyrzekając się własnej wolności, którą pragną w ten sposób zwiększyć.Po czwarte, nastąpiło wtargnięcie i atak ze strony zradykalizowanego islamu, do którego przykładowo należy 45\% brytyjskich meczetów (konkretnie do sekty Deobandi) [Philips 2016], nawet jeśli przeważająca ich większość w żaden sposób nie popiera aktów terroryzmu. To wtargnięcie zintensyfikowało powrót Boga w niezwykle złożony i często paradoksalny sposób. Niektóre siły lewicowe, obecnie często określane głównie przez swój sekularyzm, mogą strategicznie sprzymierzać się z islamistami w opozycji do zachodniego kolonializmu, państwa Izrael, a nawet, sotto voce, domniemanej żydowskiej plutokracji.Tymczasem kościoły głównego nurtu zbyt często decydują się na uproszczenie, polegające na obronie tożsamości religijnej i wolności jako takiej, nie biorąc dostatecznie pod uwagę, że co najmniej część dziedzictwa humanistycznego i świeckiego, w odniesieniu na przykład do równości kobiet, wolności religijnej i wyłączenie obszaru pola polityczno-prawnego poza sacrum, to dorobek postchrześcijański. Aby być autentycznie chrześcijańskimi, kościoły muszą uplasować się nieco pośrodku, jeśli chodzi o spór między świeckością a teokratyczną autonomią. Słuszne jest, na przykład, upieranie się, że absurdem jest wymaganie, by kobiety paradowały półnagie po plaży, chociaż należy bezwzględnie bronić ich prawa do tego, jeśli tak zdecydują. Z drugiej jednak strony kościoły powinny dołączyć do protestujących przeciwko decyzji policji szkockiej, aby zezwolić na noszenie 
hidżabu jako części policyjnego munduru. Jest to niepokojące, ponieważ nie zezwolono by na żaden tak oczywisty symbol chrześcijański, żydowski czy hinduski, i bardzo słusznie. Policjant powinien stawiać się przed nami wyłącznie jako przedstawiciel świeckiego prawa, a nie jako bezpośredni przedstawiciel jakiejkolwiek wiary. Więc to, z czym mamy tu do czynienia, to niepokojące ustępstwo wobec skrycie radykalnej presji islamu. Zamiast tego, obronie uzasadnionych praw religii muzułmańskiej na Zachodzie (w tym do stosowania prawa szariatu, o ile jego zasady nie stoją w sprzeczności z zasadami świeckiego prawa) powinno towarzyszyć żądanie wzajemności na ziemiach islamskich, gdzie dotychczas wzajemność ta raczej nie występuje.

Jednak, obecnie, im bardziej chrześcijanie potwierdzają, wbrew dowodom, że wszelki religijny „fundamentalizm” w równym stopniu wykazuje skłonność do przemocy (ilu zamachowców samobójców znajdziemy tak naprawdę w pasie biblijnym?), tym bardziej sami chrześcijanie będą padać ofiarą podejrzliwości w stosunku do religii, po każdym kolejnym występku islamistów. Jakkolwiek w starożytności na ziemi arabskiej dokonano godnych podziwu postępów za sprawą islamu, biorąc pod uwagę wcześniejszą politeistyczną przeszłość, i jakkolwiek spuścizna koraniczna była często z powodzeniem modyfikowana przez perskie, greckie, żydowskie, gnostyczne i chrześcijańskie wpływy, zarówno filozoficzne jak i mistyczne, to jednak bezsprzecznie islam stara się przywrócić archaizm prawa religijnego i „pustynnego monoteizmu” w charakterze nowego i cokolwiek przewrotnego uniwersum. Ten archaizm wynika niemal nieuchronnie $z$ roszczenia, że islam jest objawieniem wykraczającym poza objawienie chrześcijańskie. $Z$ chrześcijańskiego punktu widzenia, jak czytamy u św. Pawła, ludzkie prawo i obyczaje, demonicznego pochodzenia, zostają zastąpione przez ludzką obecność samego Boga w swojej niepowtarzalności. To jest ostateczny i paradoksalny przykład.Skłonność islamu sunnickiego głównego nurtu i ortodoksji kalamu, aby sprowadzić ład do władzy w sensie teokratycznym, lub do takiej, w której luki w boskim nakazie są wypełniane przez polecenia ludzkich tyranów, którzy czasami mogą być dziwnie postrzegani jako nieco zewnętrzni w stosunku do islamskiego porządku, wiąże się, jak twierdził Papież Emeritus Benedykt XVI w Ratyzbonie, z pewną trudnością w mediacji sacrum drogą rozumową i z wrodzoną sakralnością samego rozumu [Schaull 2007]. Ta trudność została zaobserwowana w obrębie islamu przez wielkiego teoretyka historycznego Ibn Khalduna, kiedy twierdził, że porządek pustyni podlega pewnej naturalnej dekadencji i upadkowi, gdy zostaje poddany wyrafinowanej miejskiej refleksyjności, czasami wywołując w odpowiedzi reakcję nomadyczną i rozpoczynając nowy cykl historyczny [Khaldun 2005]. Coś podobnego zostało później odnotowane w odniesieniu do całej historii ludzkości przez Neapolitańczyka Giambattistę Vico w XVIII w., ale Vico zasugerował także pewien punkt kulminacyjny osiągnięty przez katolickie 
chrześcijaństwo z jego wyjątkowym połączeniem tradycji, wyobraźni i emocji z racjonalną refleksją, z wykluczeniem wszelkiego bałwochwalstwa, czy to w odniesieniu do obrazu, czy też pojęć abstrakcyjnych [Vico 1999: 478-479].

Rozmyślając nad tym wszystkim, można by zasugerować, że im bardziej Zachód cierpi z powodu radykalnej ingerencji islamskiej i równolegle powstających irracjonalnych fundamentalizmów w samym chrześcijaństwie, tym bardziej traci równowagę i tym bardziej oscyluje w stronę Khalduny, który jest ostatecznie neopogański, mimo, że jest również przedstawicielem islamu. Tak więc dziś, gdy chrześcijański uniwersalizm zanika, coraz częściej napotykamy nierozwiązywalne napięcie między abstrakcyjną globalizacją z jednej strony, a atawistycznymi lokalizmami z drugiej, bez względu na to, czy wynikają z fundamentalizmu religijnego, czy z nacjonalizmu. Nic nie jest skończone w tym XXI w., gdy kontrrewolucyjny duch Charlesa Maurrasa, tak niedawno uważanego za równie martwego jak Karol Wielki, a teraz dziwnie zmutowany, przyodziany w płaszcz rewolucyjnego sekularyzmu, mógłby z dużym prawdopodobieństwem sięgnąć po władzę we Francji i to w całkiem bliskiej perspektywie.

\section{III.}

Wszystkie te cztery zjawiska niosą ze sobą implikacje dla teologii i kościołów, które im do tej pory nie zdołały stawić czoła. W kulturze ani w filozofii nie ma obecnie wspólnej, neutralnej podstawy, od której mogłaby wyjść liberalna teologia, i dlatego teologia liberalna jest tak wyraźnie wyczerpana. Może się zdarzyć, że chrześcijanie zgodzą się z przedstawicielami innych wyznań lub $\mathrm{z}$ ateistami $\mathrm{w}$ tej lub innej sprawie, wręcz $\mathrm{w}$ wielu sprawach, ale nigdy na ściśle zbieżnych (choć może na częściowo pokrywających się) podstawach, i nigdy z wyraźną jasnością co do granic wspólnej ludzkiej przestrzeni i obszarów zastrzeżonych dla wiary lub jej braku. Nic się bowiem nie kończy (poza samym liberalnym dogmatem, że się kończy) i wszystko jest ponownie z zasady podważalne. Jedyne, co mogą zrobić chrześcijanie to tylko raz jeszcze zająć stanowisko na gruncie chrześcijańskim.

Nie oznacza to jednak, że dzisiaj, przy nieuniknionym odrzuceniu teologicznego liberalizmu, powinniśmy prosto i bezkrytycznie przyjmować wykładnię ortodoksyjną, czy będzie ona katolicka, prawosławna, anglikańska czy protestancka. Byłoby to sprzeczne z uznaniem nadejścia sekularyzacji jako czegoś fundamentalnego dla teologii. Dlaczego ona się pojawiła? Odpowiedź może być znacznie bardziej przypadkowa i banalna niż przypuszczamy. Albowiem można dzisiaj zaobserwować, że klerowi i laikatowi brakuje często energii i zaniedbują rzeczy oczywiste, mimo, że zagubione społeczności wołają o wspólnotę, życie, dramaturgię, celebrację i sens. Tam, gdzie chrześcijanie mają coś do zaoferowania, 
zwykle osiąga się znaczną miarę sukcesu. Jednak fakt, że są to rzadkie przypadki powoduje rozpowszechnienie niedowiarstwa i zniechęcenie wraz z zawstydzeniem. $\mathrm{Z}$ tego powodu w końcu powraca podstawowy problem wiary i jej braku.

To właśnie w tym momencie chrześcijanie muszą zadać sobie pytanie, czy ich ortodoksja i ortopraksja były wystarczająco autentyczne. Można twierdzić, że tutaj wyraźnie widać konkretne problemy. Charles Taylor argumentuje, że laicyzacja wynikała z odrzucenia doktryny piekła i opartej w zbyt dużym stopniu na lęku dyscypliny etycznej i duszpasterskiej, albo też, jak na ironię, z sekularyzacji dyscypliny etycznej, która uwolniła się od wszelkich obrządków i celebracji religijnych. Być może jest jakaś przewrotna prawda w uproszczonej opinii, że ludzie odrzucają chrześcijaństwo z powodu odrazy i chęci odrzucenia lęku przed wiecznym potępieniem oraz sprzeciwu wobec ingerencji duchownych $\mathrm{w}$ ich prywatne i społeczne uciechy.

W obu przypadkach, piekła i zastąpienia świętowania dyscypliną, należało by zapytać, czy nominalna ortodoksyjność była w pełni zgodna z jej biblijnymi, liturgicznymi i patrystycznymi korzeniami? Niemal na pewno nie ma w Nowym Testamencie doktryny o wiecznej karze, podczas gdy oryginalna wyznaniowa ortodoksja, jak u Orygenesa, Ireneusza i Kapadocjan, została opracowana zgodnie z logiką, która nie tylko jej nie obejmowała, ale wskazywała na ostateczne pojednanie eschatologiczne wszystkich rzeczy i na nim się opierała [Hart 2015: 1-17; Ramelli 2013] . Taka doktryna najbardziej radykalnie głosi wszechmoc Boga, jednak interpretuje tę wszechmoc jako wszechmoc miłości.

Z kolei bez apokatastazy Bóg jawi się albo jako tyran, albo jego wszechmoc jest na różne sposoby kwestionowana. Augustyn i Tomasz z Akwinu nie byli winni tego rodzaju odchyleń, które znajdujemy w późnośredniowiecznej myśli i jej skłonności do błędnego przeciwstawiania sobie woli stworzonej skończoności i woli twórczej boskości, jak gdyby znajdowały się w tym samym wymiarze rzeczywistości. Jednak może w dłuższej perspektywie to właśnie doktryna o wiecznym potępieniu skłania do tej dewiacji, wraz z powiązaną koncepcją, która przeciwstawia zastrzeżoną absolutną wolę Boga jego woli zamierzonej i twórczej, i wynikającej z tego idei podwójnej predestynacji ${ }^{4}$. Przede wszystkim może to

3 Przygnębiająca i śmieszna próba Ojca Johna Whiteforda, by odrzucić Hart’a, wymaga od niego uznania Grzegorza z Nyssy, Maksyma Wyznawcę i Izaaka Syryjczyka, nie mówiąc o nadzwyczajnym i wielkim Orygenesie, za „heretyków”.

4 Tu zgoda z twierdzeniem Davida Bentley’a Harta, że późnośredniowieczne odchylenia wiążą się ostatecznie z pewnymi tendencjami u późnego Augustyna, z jego zapewne podświadomym odejściem od głównego nurtu liturgicznego i partycypacyjnego z pism wczesnych i z okresu pośredniego. 
prowadzić do stopniowej utraty poczucia uczestnictwa jako fundamentalnie wynikającego z idei stworzenia przez Boga, w którym „żyjemy, poruszamy się i jesteśmy” $(\mathrm{Dz} 17,28)$ bez żadnych zastrzeżeń.

Bowiem, jeśli piekło przez całą wieczność istnieje poza Bogiem, a Bóg w pewnym sensie chce tego, lub na to pozwala, to może się wydawać, że w sposób świętokradczy dopuściliśmy do tego, by istniał obszar bytu ontologicznie niezależny od Niego. Stąd dominacja jednoznacznej ontologii po Bonawenturze i Szkocie może być również w jakiś sposób związana z tym założeniem, ponownie w bardzo długim okresie.Późnośredniowieczny zwrot $\mathrm{w}$ stronę woluntaryzmu, który nastąpił do pewnego stopnia pod wpływem islamu, jak słusznie zauważył w Ratyzbonie Papież Emeritus Benedykt XVI, był często aprobowany w imię silniejszego odrzucenia pogaństwa i pogańskiego charakteru neoplatońskiego dziedzictwa. Tak więc nieodłączna symbolika i ewokacja Boga w porządku stworzonym były traktowane nieufnie jako nazbyt deterministyczne [Honnefelder 2005]. Skutki tego odrzucenia były jednak paradoksalne. Wiązały się silnie z wpływem Awicenny, który połączył arystotelesowski determinizm i rodzaj zatomizowanego platonizmu niezmiennych jednoznacznych esencji z elementami islamskiego boskiego wyboru i proroczej inspiracji [Milbank 2015a: 41-117]. Niektórych jego chrześcijańskich czytelników prowadzi to do jeszcze wyraźniejszego dualizmu: na przykład u Henryka z Gandawy, a jeszcze bardziej u Dunsa Szkota widzimy absolutne przeciwstawienie natury i woli, które determinują całą ich teologię [Gilson 2013]. Tylko dlatego, że wolność jest gwarantowana jedynie w absolutnym kontraście do konieczności, ten sam gest, który zmierza do utrzymania czystości woli, paradoksalnie przywołuje jako swój cień sferę stałych natur, z których nawet Bóg jest zmuszony wybrać - sferę, która ostatecznie na Zachodzie staje się sferą rozczarowanej, czystej służalczości wobec praw braku sprzeczności, matematyki i nieubłaganego mechanizmu fizycznego.Dlatego też, starając się uniknąć pogaństwa symboliki i pokrewieństwa, teologowie ci wywołali w to miejsce widmo czystego ślepego fatalizmu pogańskiego, choć zrobili to, jak na ironię, w imię wytępienia wszelkich „racjonalnie koniecznych” pogańskich śladów. Aby powrócić do wcześniej przywołanego toposu magii, dążąc do wyeliminowania wszelkiej „białej magii” jako koniec końców diabelskiej, odwołali się do tajemnej faustowskiej ciemności czystej kontroli nic nieznaczących sił nad czystą mocą. Już wtedy, w sferze ładu, ładu należącego do religii, zaczęli wznosić bożka władzy, przewrotnej władzy sprawowanej przez ład. Tym samym usunęli centralną chrześcijańską koncepcję boskich rządów, która łączy „teologię polityczną” Biblii, w myśl której Bóg jest władcą wszechświata, z grecką refleksją nad Bytem jako takim i jego podstawowymi podziałami [Agamben 2011: 1-16, 53-67; Milbank 2013: 1-18; Milbank 2017]. 
Ta fuzja, którą antycypuje biblijna tradycja mądrości, ostatecznie skłania się ku jednej tendencji we wczesnej religii hebrajskiej, która odziedziczyła względną mroczność i fatalizm bliskowschodniego politeizmu, bardzo oddalonego od gajów Morza Śródziemnego. Kapryśnym i krwiożerczym w swojej woli bóstwom przeciwstawiono absolutną wolę Boga Izraela i wszelkiego stworzenia [Debray 2014: 16-105, 129-130]. To jest ten „pustynny monoteizm”, czy też „magianizm” (jak go określił Oswald Spengler) [Spengler 1991: 341], który sunnicki islam głównego nurtu nieco zaskakująco ożywia i w taki sposób, że to może się jawić bardziej jako „powszechny henoteizm” niż rzeczywisty monoteizm wymagający czegoś na wzór neoplatońskiej myśli o Jedynym jako ontologicznie wykraczającym poza ontyczność. Oryginalnie określano go jako ontologiczny nadmiar. Oczywiście niektóre nurty islamu przyswoiły sobie właśnie takie określenie znaczenia prawdziwej, absolutnej i transcendentnej jedności, ale to właśnie tego rodzaju korzyści, wraz z towarzyszącym temu dopuszczeniem partycypacyjnego i sakramentalnego pośrednictwa świętych i świętych miejsc, którym wahabici, salafici i pokrewne współczesne nurty islamu zaprzeczają. Podobnie jak w historii części kalwinizmu, duch ikonoklazmu i duch antyludzkiej przemocy nie są tak odległe od siebie [Noyes 2016].

W porównaniu z odejściem od ładu, czy też od „teopolitykoontologii” boskiego rządu, wydarzenie Reformacji ma niewielkie znaczenie, ponieważ jedynie połowicznie odrzuciło tę zmianę, a częściej ją podtrzymywało i intensyfikowało. Być może teraz zrozumiemy, że nurty renesansowego neoplatonizmu i hermetyzmu, później podtrzymywane przez wielu po obu stronach poreformacyjnego podziału, muszą zostać ponownie zbadane pod kątem ich ortodoksji, jak to się już dzieje w przypadku młodszych teologów, takich jak Michael Martin w USA, i następuje za przykładem Hansa Urs von Balthasara i rekomendowanych przez niego hermetycznych i sofistycznych refleksji Valentina Tomberga [Balthasar 2002: 659-665; Martin 2015]. W obliczu na poły woluntarystycznej, na poły fatalistycznej teologii Terministów w późnym średniowieczu, wynikającej z ich ścisłego racjonalizmu, który miał tendencję do bezwzględnego, rygorystycznego stosowania prawa niezaprzeczalności jako jedynego probierza filozoficznego, myśliciele renesansu od Cusa przez Ficino po Roberta Fludda i Thomasa Vaughana mogli w istocie uważać, że wielką ortodoksyjną tradycję symbolicznego realizmu i jej autentyczną hebrajsko-grecką hybrydę, niezbędną prawdziwej ortodoksji, można ocalić tylko poprzez uznanie jej bardziej hiperracjonalnych elementów nieredukowalnej zaprzeczalności, naturalnego magicznego powinowactwa i tak dalej. W kulturze zachodniej, aż do romantyzmu, elementy te były coraz częściej uważane za bardziej dostępne dla emocji i wyobraźni, niż dla rozumu, odmalowywanego jako rzekomo czysty rozum.Ta „alternatywnie nowoczesna” tradycja, jak coraz mocniej się przekonujemy, nigdy nie odeszła, nawet w okresie Oświecenia, i jest przynajmniej tak samo odpowiedzialna, od XII w., za 
rozwój współczesnej nauki i uznanie interwencji człowieka w naturę za dopuszczalną, jak spuścizna nominalizmu i mechaniki. W rzeczy samej, jej subtelność pozwala w większym stopniu antycypować tajemnice współczesnej fizyki, podtrzymując jednocześnie, podobnie jak mechanika kwantowa, poczucie, że światu fizycznemu nie musi być obcy subiektywizm, a zatem i oddziaływanie władzy na preferencyjne przesłanki porządku [Benz 2015; Gatti 1999]. Jak zauważył Henri de Lubac, historycznie Prometejczyk mógł zajść dalej z pobożnym mechanistą niż z uznanym magiem, nawet jeśli trzeba zdecydowanie przyznać, że symbolizm porusza się niekiedy po stronie ciemności i manipulacji [Milbank 2015b: 53-61].

Jeśli chodzi o drugie religijne źródło sekularyzacji, porzucenie świętowania na rzecz dyscypliny, to stanowi ono pod wieloma względami praktyczny odpowiednik tego samego przejścia od autentycznego ładu do ładu ustanowionego poprzez sprawowanie władzy. Zamiast uciekać się do rytualnego odtworzenia i próby przywołania wiecznego porządku, który pozostawał w ciągłości z ludową ekstazą i świętowaniem (jak argumentował Charles Taylor powołując się na Ivana Ilicha), zachodni chrześcijanie w okresie średniowiecza coraz bardziej podkreślali wagę indywidualnych zasług i postępowania, traktując nawet rytuał w kategoriach mechanicznego obowiązku, w formie, która ostatecznie została w końcu słusznie oprotestowana przez protestantów.

Jednak większość wczesnych nowoczesnych chrześcijan, czy to protestantów, czy katolików, nadmiernie koncentrowała się na indywidualnej moralności jako drodze do zbawienia lub jako świadectwie jego istnienia, w sposób, który pomniejszał problematyczną, a często tragiczną, ciągłość tego, o czym możemy decydować, wraz z aspektami naszej naturalnej i kulturowej sytuacji oraz kolektywnego dziedzictwa, o których nie decydujemy i którym możemy jedynie stawiać czoła, i w pewien mniej lub bardziej tajemniczy sposób przekształcać, poprzez religijną pobożność i liturgiczną celebrację [Milbank 2015c: 69-86]. Chrześcijański Wschód rozumiał to lepiej. Tam cała etyczna i medyczna praktyka mieściła się w szerszej symbolicznej i rytualnej treści, co tak sugestywnie ilustruje niedawno wydana rosyjska powieść Laurus, Jewgienija Wodołazkina, osadzona w rosyjskim średniowieczu [Vodolazkin 2016]. Z kolei efektem tego podejścia na Zachodzie było historyczne podporządkowanie świeckich, pogarda dla zwyczajów ludowych wraz z bardziej pozytywnymi pozostałościami pogańskimi ${ }^{5}$, i pozbawiona wyobraźni surowość wobec kwestii seksual-

5 Lepiej poradziły sobie średniowieczne Irlandia, Walia i Islandia - świadczą o tym wyjątkowe synkretyczne dzieła literackie takie jak irlandzkie Colloquy of the Ancients (Agallamh na Seanórach), walijski Mabinogion oraz islandzka Poetic Edda (Edda poetycka). Podobnie w przypadku Gruzji na wschodzie i jej XII-wiecznego eposu, The Knight of the Panther Skin (Rycerz w tygrysiej skórze). Gruziński i ormiański synkretyzm został ponownie przywołany w filmach Siergieja Paradżonowa. 
nych (co nie oznacza, że Wschód był całkowicie wolny od takich wad). Twierdzę zatem, że potrzebujemy dziś radykalnej ortodoksji, skupionej, tak jak u zarania chrześcijaństwa, na apokatastazie, uczestnictwie, immanentnej boskiej obecności, która obejmuje w równym stopniu transcendencję, symboliczny realizm i centralne usytuowanie liturgii, w charakterze teurgicznego odtworzenia uznanego za spełnione we Wcieleniu i Eucharystii.

IV.

Co to oznacza dla przyszłego nauczania teologii? Można utrzymywać, że od czasu Schleiermachera, teologia kopała swój własny grób poprzez nadmierną profesjonalizację i nadmierne ustępstwa wobec świeckich norm. Podobnie jak w przypadku ortodoksji jako takiej, tak w przypadku teologii, powinniśmy zapytać, jaki jest prawdziwy charakter chrześcijańskiego nauczania, czy też doctrina Christiana, jak je nazwał Augustyn? Od czasów baroku, a jeszcze bardziej od czasów współczesnej teologii uniwersyteckiej początku XIX w., myśleliśmy o teologii jako po pierwsze odrębnej od filozofii, a po drugie podzielonej na różne subdyscypliny. Najpierw zajmijmy się tym ostatnim: rezultat wyodrębnienia studiów biblijnych i historii Kościoła od reszty teologii wywołuje często dziwny rodzaj dwójmyślenia. Z jednej strony są one uważane za fundamentalne dla całej teologii, biorąc pod uwagę, że chrześcijaństwo jest historycznie objawioną i rozwijającą się religią. Z drugiej strony, są one również postrzegane jako dyscypliny stricte krytyczne, zewnętrzne wobec teologii jako takiej. Wydaje się, że celem jest zyskanie wiarygodności w środowisku akademickim i wśród świeckich poprzez oparcie teologii na czymś jednoznacznie pozytywnym, co, jak wszelka pozytywność, jest poparte władzą i odwołuje się do niepodważalnych oznak władzy inaczej znanych we wczesnej nowoczesności jako „fakty”. To jednak, oczywiście, prowadzi do błędnego zrozumienia objawienia, które płynie z potrójnego boskiego źródła osobowości do ludzi oraz poprzez ludzi, już w formie ich odpowiedzi, która jest liturgiczna.

Cel, jakim jest zyskanie uznania jest ostatecznie skazany na niepowodzenie, co potwierdza się dzisiaj coraz częściej, ponieważ świecka akademia koniec końców nie znajdzie powodu, aby ściśle obiektywne studia nie mogły być przemiennie umieszczone w ramach studiów bliskowschodnich, klasycznych, historycznych, itp.

Zamiast tego podejścia musimy teraz uznać, że to, co pozornie trudniej obronić w rzeczywistości może być do obrony łatwiejsze, gdyż w ten sposób teologia może zaoferować reszcie akademii coś, czego nikt inny nie potrafi - mianowicie spójny tytuł do pośrednictwa w absolucie poprzez naturę i historię. Bez dyskusyjności tego tytułu, można by argumentować, zasadnicza debata uniwersytecka pomiędzy roszczeniami władzy i porządku musi z konieczności wygasnąć. Dlatego potrzebujemy prawdziwie „teologicznej teologii”: 
wydziałów, w których wszyscy ci, którzy zajmują się subdyscyplinami, pozostają jednak teologami, w pełnym znaczeniu systemowym i filozoficznym. Nie ma sensu, by zamiast tego mianowano jedną lub dwie osoby w ramach ukłonu czy próby obłaskawienia kościołów - które i tak, popadając niebezpiecznie w antyintelektualizm, coraz mniej wymagają i doceniają tego rodzaju przejawy uznania.

Wracając do punktu pierwszego: do przyjętego oddzielenia teologii od filozofii. Rezultatem tej separacji jest to, że teolodzy, przynajmniej w swoim początkowym programie studiów, zwykle zajmują się jedynie filozofią religii, a nie filozofią jako taką, włącznie z jej najbardziej podstawowym obszarem, czyli ontologią. To ograniczenie nieuchronnie skazuje teologię na kulturową i akademicką marginalizację, ponieważ oznacza, że z założenia nie ma nic istotnego do powiedzenia o tym czym coś jest, oraz o tym, co to znaczy czymkolwiek być. Zamiast tego, teologia jest postrzegana jako dyskurs poboczny w dziedzinie bytu, jako zbiór problematycznych argumentów na temat ostatecznych przyczyn skończonego bytu i jako źródło dyskusyjnej tezy o objawieniu w tej dziedzinie.

Jednak stawianie sprawy w ten sposób przesądza o wszystkich fundamentalnych pytaniach chrześcijańskich i zapewne prowadzi do zdrady prawdziwego, pierwotnego, chrześcijańskiego dziedzictwa intelektualnego. I co ważniejsze, powoduje powtórzenie późnośredniowiecznego zniesienia boskiego rządu i podział rzeczywistości pomiędzy neopogański fatalistyczny byt z jednej strony, a bóstwo zasadniczo charakteryzujące się wolą wykraczającą poza naturalne ograniczenia z drugiej. Tak więc, jak wykazał obecnie Olivier Boulnois, terminy i dyscypliny „ontologii” (metafizyki, która ostatecznie porzuciła twórcze i aporetyczne wahanie się Arystotelesa między prymatem Boga a prymatem Bytu) i ,teologii naturalnej” (racjonalne dociekanie Boga jedynie na obrzeżach ontologii) pochodzą z jednego źródła [Boulnois 2013: 313-341]. Wcześniej, tak jak w przypadku Tomasza z Akwinu, metafizyka przede wszystkim dotyczyła bytu, ale potem osiągnęła spełnienie poza własną materią, dochodząc do twórczej przyczyny wspólnego bytu jako takiego, ens commune, a nie tylko bytu ograniczonego do swoich form skończonych, w których niejako przygodnie istnieje (wynika z tego, że u Akwinaty nie ma czegoś takiego jak „teologia naturalna”). Zatem, dla Tomasza z Akwinu, w przeciwieństwie do Szkota, istnienie w samym swoim bycie nie jest jedynie „dane”, ale jest oznaczone w swoim centrum, a jednak poza nim jako dar i udział w boskiej naturze, która zbiega się z czystym „być” lub esse. Ponieważ teologia właściwa metafizyce jest nierozerwalnie związana z całą metafizyką, teolog, jak go pojmuje Akwinata, najpierw bada całą ontologiczną domenę filozofii, choć przez dochodzenie do nieznanej przyczyny właściwie ujawnionej jedynie przez objawienie otwiera drogę do ponownego dokonania dystrybucji ontologicznej $\mathrm{w}$ formie manifestacji samego esse w bosko-ludzkim zdarzeniu [Boulnois 2013: 189-311]. 
Wcześniej i jeszcze bardziej radykalnie, w przypadku zdumiewającej syntezy patrystycznego Wschodu i Zachodu autorstwa irlandzkiego i karolińskiego myśliciela, Jana Szkota Eriugeny, obserwuje się jeszcze dalej posuniętą integrację filozofii z teologią, do której później powrócą Eckhart i Mikołaj z Kuzy w związku z rozłamami związanymi ze skotyzmem i terminizmem. Albowiem to tu, jak wykazał Jean Trouillard, znajdziemy również dalszy rozwój samej tradycji neoplatońskiej i rozwiązanie niektórych jej dylematów w kategoriach ściśle chrześcijańskich [Trouillard 2014].

W przypadku teurgicznego neoplatończyka Proklusa, poza perspektywą pierwszego neoplatończyka Plotyna, materia z samego dołu skali uzyskała pewne wyjątkowo czyste i nierefleksyjne ( $w$ przeciwieństwie do inteligencji) zdolności obrazowania transcendentnego Jedynego, co pozwoliło jej stać się wehikułem rytuału i sakramentu. Taki rozwój doprowadził do neoplatońskiego odrzucenia gnostycznego traktowania materii jako błędu [Trouillard 2014: 251-272]. Jednak przewagą gnostycyzmu było wyjaśnienie, w kategoriach dramatycznych, przygodności i braku konieczności ontologicznego lapsusu. Chrześcijaństwo, wraz z Orygenesem i Ireneuszem, efektywnie wyszło zarówno poza neoplatonizm, jak i gnostycyzm, proponując ideę dramatu zakłócenia, które na jakiś czas zepsuło zarówno ciało, jak i duszę, a następnie jedno i drugie zostało odkupione, by niczego nie porzucać [Pickstock 2013: 171-192].

W przypadku Eriugeny ta synteza wychodzi na czoło, wobec czego cielesność jest postrzegana jako odpowiedni środek dla teofanii; ostatecznie zostajemy wyniesieni nie jedynie ponad ciało, ale wraz z ciałem przywróconym przez przemienienie do jego prawdziwej, stworzonej esencji duchowej. W odróżnieniu od Akwinaty, zmartwychwstanie jest uważane zarówno za naturalne przeznaczenie metamorfozy wszelkiego życia z powrotem do źródła, które jest także jego spełnieniem, oprócz tego, że jest jednocześnie dziełem darmowej łaski, ponieważ stworzenie jest w całości wolnym darem, zatem to co suplementarne ma paradoksalnie znaczenie fundamentalne [Trouillard 2014: 99-131, 159-164, 251-272]. Na mocy tej radykalnie teofanicznej perspektywy Eriugena nie pozostawia żadnej drogi otwartej w kierunku późniejszej i nieautentycznej dwoistości jedynie nadanej natury, jako należącej do obszaru władzy oraz daru łaski uważanego w zbyt dużym stopniu za dzieło kapryśnego ładu, w przeciwieństwie do tego co marginalnie czyni Tomasz z Akwinu [Milbank 2015b: 85-93].

W ten sposób zostaje uwzględniona zarówno chwała materialnego pośrednika jako stworzonego i będącego odbiciem Jedynego, chwała będąca nośnikiem kształtu i znaku, jak i jego niski status (gdyż jest postrzegany jako przygodnie upadły), a przyrodzona szlachetność 
ciała jako zasłony i jednocześnie objawienia Boga zostaje eschatologicznie przywrócona. Wychodząc poza neoplatonizm, inny wobec Jedynego jest objęty końcowym przeznaczeniem, gdy „stworzony Bóg”, będzie zjednoczony, choć nie całkiem scalony, z „niestworzoną i niestwarzającą" oryginalną i trwałą jednością wszystkiego.

Rzeczywistość ontologiczna jest rekonstruowana przez Eriugenę jako rodzaj wiecznej trynitarnej metahistorii, w której Bóg będący ostateczną zasadą istnieje w tym sensie, że stwarza siebie poza własną, niejako „pierwotną” nieopisywalną ojcowską i przez to niepoznawalną nieskończonością (za Grzegorzem z Nyssy), jakby po wszelkim poznaniu, i zna siebie jako tworzącego w Synu, a przez to relacyjnie i dynamicznie żyje i „efektywnie” porusza się w Duchu [Trouillard 2014: 153-158]. Rzeczywistość stworzona jest jednocześnie z konieczności skończoną realizacją tego procesu, włączając w to pierwsze stworzenie początkowych boskich idei jako pierwotnych, generujących skończone zasady (porównaj zarówno logoi Maksyma jak i rationes seminales Augustyna) i wyraźnym manifestacyjnym udziałem jej docelowej nieskończoności i wieczności. Biorąc pod uwagę ten podwójny aspekt równoczesnej boskiej kompozycji i teofanicznej manifestacji, każde indywidualne stworzenie, w różnym stopniu, jest postrzegane przez Eriugenę jako znające siebie w procesie, w którym się stwarza - na zasadzie zewnętrznego teurgicznego dzieła intelektu informującego ciało, a nie wewnętrznego „idealistycznego” zjawiska projekcji umysłowej'. Zgodnie z tą samą logiką uczestniczenia w Trynitarnym procesie, stworzenia zarówno wzajemnie się znają jak i tworzą (w tym ludzie i anioły) na różnych poziomach mistycznej gnozy, rozumu, wyobraźni, wspólnych odczuć i cielesnych interakcji [Eriugena 2011, IV, 780 a-c; Trouillard 2014: 214-223].

W tej ontologii, w ciągłości z Plotynem, emanujący ruch jest bardziej pierwotny niż substancja, ponieważ myśleć to generować (wykraczając poza statyczną wewnętrzność Arystotelesowskiego „aktu”), a życie intelektualne jest najwyższą formą rzeczywistości pod niewysłowialnością Jedynego. Ta ostatnia wychodzi poza przeciwstawienie ruchu i odpoczynku (nie ma tutaj żadnej sugestii o nowoczesnej „teologii procesu”, nawet jeśli występują tu pewne filozoficzne pokrewieństwa z Whiteheadem), i to raczej odpoczynek niż ruch wyznacza relatywny brak życia niższym poziomom rzeczywistości [Plotinus 1984: II, VI]. Tak więc dla Eriugeny nie ma kontrastu między metafizyczną „nadnaturą” z jednej strony i fizyczną „naturą” z drugiej. Zamiast tego, dla czegoś, co można by opisać jako jego

6 W mojej opinii istotne jest, by unikać postkartezjańskiego, kantowskiego i heglowskiego anachronizmu czytając w tym miejscu Eriugenę. Jeśli chodzi o przeciwstawienie dwóch różnych „kreacji”, czy „konstrukcji”, wewnętrznej i zewnętrznej, patrz Milbank, Beyond Secular Order [Milbank 2013: 208-211]. 
„parafizykę", natura jako ruch emanujący jest wszechogarniającą zasadą całej rzeczywistości, a „podział natury” pokrywa się z nauką samego Boga ${ }^{7}$.

Czy ów teologiczny i metafizyczny schemat jest heterodoksyjny, czy raczej hiper, lub radykalnie ortodoksyjny ze względu większą uwagę, bez niepotrzebnego wytłumienia, skupioną na paradoksie egzystencji stworzonej „na zewnątrz” Boga, który jest jednak wszechobecny, a zatem bez zewnętrzności? I podobnie skupioną w większym stopniu na trynitarnej prawdzie, że wiedza jest manifestacją i konstrukcją, nawet jeśli wywiedzioną teleologicznie, daleko wybiegającą poza większość zwykłych realizmów czy idealizmów? A także ze względu na przyjęcie plotyńskiej nadrzędności ruchu jako lepszego sposobu na wyrażenie chrześcijańskiej ontologii jako trynitarnej?

Sugerowałbym, że powinniśmy go uznać za hiperortodoksyjny, jeśli mamy odpowiedzieć na sekularyzację, która, jak starałem się wykazać, w dużej mierze wynikała z reakcji na wypłonioną zachodnią ortodoksję, a zwłaszcza na jej podważanie boskiej prostoty poprzez założenie, że Bóg „dokonuje wyborów” w sensie stanowczo zbyt antropomorficznym. Eriugena "rozwiązuje” aporetyczną koincydencję kreowanej konstytucji i kreowanej manifestacji „wcześniejszego", pełnego Boga, w kategoriach eschatologicznego przyjścia, gdy Bóg jest wszystkim we wszystkich - dokonanym spełnieniem, które było od zawsze $\mathrm{w}$ centrum tego co rzeczywiste. Wszystko to w pewnym sensie jest tak naprawdę protoheglowskie, ale w przeciwieństwie do Hegla, nie ma momentu niezbędnej alienacji ani determinacji poznania przez negatywną logikę, w opozycji do wynikającego z pozytywnej woli, a zarazem teofanicznego aktu stworzenia, który stanowi jednocześnie estetyczną ekspresję, jest „obiektywnie prawdziwy” ponad wszelkie logiczne procesy ${ }^{8}$. Pojawienie się alienacji, utrata intuicji i pogłębiająca się niewydolność naszych oryginalnych ciał to wszystko przygodne skutki naszego upadku.

Ale odkupienie od tej kondycji dla Eriugeny, o wiele bardziej zdecydowanie niż dla Akwinaty, nie wspominając o większości późniejszych szkół teologii, jest po prostu działającym

7 Widać, że Akwinata wychodzi poza wpływy arystotelesowskie, kiedy proponuje ontologię wzrastającej skali coraz bardziej intymnych emanacji w SCG 4.11 oraz w swoim Compendium Theologiae.

8 W XIX-wiecznej szkole tybińskiej proponowano myśl Eriugeny jako bardziej wyrafinowaną i bardziej ortodoksyjną alternatywę dla heglizmu w książce Franza Antona Staudenmaiera, nawet jeśli ten ostatni później wycofał się z tego poglądu. Jego intuicyjny zwrot ku Eriugenie skomentował potem Balthasar, choć ten z kolei z większą ostrożnością wskazał raczej na Maksyma. Można jednak twierdzić, że ta preferencja miała złagodzić znaczenie przeplatania Maksyma Augustynem u Eriugeny, jak również jego własną odnowioną i bezpośrednią interakcję z neoplatonizmem, jak utrzymuje Trouillard (podobnie jak Balthasar kolejny adept nouvelle théologie) [O’Regan 2014: 276-290]. 
i nieuchronnym triumfem pierwotnego porządku natury, który jednak obejmuje porządek łaski. Echaton jest wobec tego tyleż ontologiczny, co metahistoryczny, i w żadnym razie nie jest arbitralnym spełnieniem, przygodnie zależnym od woli bóstwa.

W takim starochrześcijańskim światopoglądzie ład i władza, otoczenie ontologiczne i ujawnione zdarzenie to nierozłączne aspekty szerszej teorii rzeczywistości, która jest zarówno ontologiczna, jak i historyczna, jawi się w kategoriach zarówno boskiego rządu, jak i boskiego dramatu ratowania boskiej chwały. I dlatego dyskurs Eriugeny, podobnie jak i Tomasza z Akwinu, choć w jeszcze większym stopniu, tak naprawdę nie ma dzisiaj dla nas nazwy dyscyplinarnej. Ale jestem przekonany, że teologia powinna znów podążyć tym torem, jeśli chce mieć jakiś rzeczywisty współczesny wpływ w sytuacji, w której Bóg powrócił, ale na razie jedynie w formie kontestacji. Nic się nigdy nie kończy, aż do eschatologicznego końca apocatastasis, a prawdziwie ortodoksyjna teologia nie skończy się, jeśli zacznie go ponownie antycypować.

tł. z jęz. angielskiego Beata Barszczewska

John Milbank - teolog anglikański, profesor religii, polityki i etyki uniwersytetu w Nottingham, współzałożyciel ruchu Radykalnej Ortodoksji, dyrektor Centrum Teologii i Filozofii Uniwersytetu w Nottingham. Opublikował m.in. Theology and Social Theory: Beyond Secular Reason (1990), The Future of Love: Essays in Political Theology (2009), The Politics of Virtue: Post-Liberalism and the Human Future (2016). 


\section{Bibliografia:}

Agamben G. (2011), The Kingdom and the Glory: For a Theological Genealogy of Economy and Government, tłum. L. Chiesa, Stanford UP, Stanford CA.

Barnett S. J. (2003), The Enlightenment and Religion: The Myths of Modernity, Manchester UP, Manchester.

Benz E. (2015), The Theology of Electricity, tłum. W. Taraba, Wipf and Stock, Eugene OR.

Boulnois O. (2013), Métaphysiques rebelles: Genèse et structures d'une science au Moyen Ăge, PUF, Paris. Burke E. (2001), Reflections on the Revolution in France, Stanford UP, Stanford CA.

Cobbett W. (2012), A History of the Protestant Reformation in England and Ireland [1827], Tan Books, Charlotte NC.

Cowling M. (1963), Mill and Liberalism, CUP, Cambridge.

Debray R. (2014), God: An Itinerary, tłum. J. Mehlman, Verso, London.

Debray R. (2017), Le Nouveau Pouvoir, Cerf, Paris.

Doyle W. (2001), The French Revolution: A Very Short Introduction, OUP, Oxford.

Eriugena J. S. (2011), De Divisione Naturae, tłum. M. L. Uhlfelder, Wipf and Stock Publishers, Eugene OR.

Gatti H. (1999), Giordano Bruno and Renaissance Science, Cornell UP, Ithaca NY State.

Gilson E. (2013), Introduction à ses positions fondamnetales, Vrin, Paris.

Harari Y. N. (2016), Homo Deus: A Brief History of Tomorrow, Harvill Secker, London.

Honnefelder L. (2005), Johannes Duns Scotus, C.H. Beck, Munich.

Hart D. B. (2015), God, Creation and Evil: The Moral Meaning of creation ex nihilo, „Radical Orthodoxy:

Theology, Philosophy, Politics", vol. 3, no. 1 (September 2015).

Jacob M. C. (2006), The Radical Enlightenment: Pantheists, Freemasons and Republicans, Cornerstone, Lafayette LA.

Khaldun I. (2005), The Muqqadimah: An Introduction to History, tłum. F. Rosenthal, Princeton UP, Princeton NJ.

Lewis C. S. (1965), That Hideous Strength, MacMillan, London.

Martin M. (2015), The Submerged Reality: Sophiology and the Turn to a Poetic Metaphysics, Angelico, Kettering $\mathrm{OH}$.

Mason P. (2016), Postcapitalism, Allen Lane, London.

Meillassoux Q. (2006), Aprés la finitude: essai sur la necessité de la contingence, Seuil, Paris.

Milbank J. (2006), Theology and Social Theory, Blackwell, Oxford.

Milbank J. (2007), Only Theology Saves Metaphysics: On the Modalities of Terror w: Belief and Metaphysics, red. P.M. Candler, C. Cunningham, SCM, London.

Milbank J. (2010), The Mystery of Reason w: The Grandeuur of Reason: Religion, Tradition and Universalism, red. P.M. Candler, C. Cunningham, SCM, London.

Milbank J. (2013), Beyond Secular Order: The Representation of Being and the Representation of the People, Blackwell, Oxford.

Milbank J. (2015a), Trinitarian Metaphysics after Albert the Great and Thomas Aquinas w: Tomismo Creativo: Letture Contemporanee del Doctor Communise, red. M. Salvioli, ESD, Bologna.

Milbank J. (2015b), The Suspended Middle: Henri de Lubac and the Renewed Split in Modern Catholic Theology, Eerdmans, Grand Rapids MI.

Milbank J. (2015c), On the Paraethical: Gillian Rose and Political Nihilism, „Telos”, vol. 173 (Winter 2015).

Milbank J. (2017), Oikonomia Leaves Home: Theology, Politics and Governance in the History of the West, „Telos”, vol. 178 (April 2017).

Monod P. K. (1989), Jacobitism and the English People, CUP, Cambridge.

Moyn S. (2015), Christian Human Rights, Pennsylvania UP, Philadelphia PA.

Noyes J. (2016), The Politics of Iconoclasm: Religion, Violence and the Culture of Image-Breaking in Christianity and Islam, IB Tauris, London. 
O'Regan C. (2014), The Anatomy of Misremembering: Von Balthasar's Response to Philosophical Modernity, tom I, Herder and Herder, New York.

Philips M. (2016), It's pure myth that Islam is a „religion of peace”, „The Times”, Friday, August $26^{\text {th }}, 2016$.

Pickstock C. (2013), Repetition and Identity, OUP, Oxford.

Plotinus (1984), Enneads, tłum. A. H. Armstrong, Harvard University Press, Cambridge MA.

Priest G. (1995), Beyond the Limits of Thought, CUP, Cambridge.

Ramelli I. L. E. (2013), The Christian Doctrine of Apokatastasis: A Critical Assessment from the New Testament to Eriugena, Brill, Leiden.

Schaull J. V. (2007), The Regensburg Lecture, St Augustine's Press, South Bend IN.

Sheldrake R. (2013), The Science Delusion, Coronet, London.

Spengler O. (1991), The Decline of the West: An Abridged Edition, tłum. Ch. F. Atkinson, OUP, Oxford. Szechi D. (1994), The Jacobites: Britain and Europe, 1688-1788, Manchester UP, Manchester.

Taylor Ch. (2007), A Secular Age, Harvard UP, Harvard MA.

Tolkien J. R. R. (1972), On Fairy Stories w: tenże, Tree and Leaf, Unwin, London.

Trouillard J. (2014), Jean Scot Erigène, Hermann, Paris.

Vico G. (1999), The New Science, tłum. D. Marsh, Penguin, London.

Vodolazkin E. (2016), Laurus, tłum. L. C. Hayden, Oneworld, London.

von Balthasar H. U. (2002), Afterword w: Anonymous, Meditations on the Tarot: A Journey into Christian Hermeticism, tłum. R. Powell, Putnam, New York. 